\title{
Cephalic index in sexual dimorphism and racial diversity: a mini review
}

\begin{abstract}
Craniometry and cephalometry are useful in classification of race and sex of individuals of unknown identity. This is a synoptic capture of cephalic index and cephalic dimensions in different populations. Cephalic index of females was higher than that of males in most populations with mesocephalic head shape in both sexes. Cephalic length and breadth of Indians were higher than those of Nigerians. Cephalic length and breadth were higher in male than female. Cephalic index and dimensions are important parameters in identification of both sexes and races.
\end{abstract}

Keywords: cephalic index, anthropometry, skull
Volume 5 Issue I - 2018

\author{
Chinna Nneka Orish \\ Department of Anatomy, University of Port-Harcourt, Nigeria
}

Correspondence: Chinna Nneka Orish, Department of Anatomy, Faculty of Basic Medical Science, University of PortHarcourt, Rivers State, Nigeria, Tel +234706574463 I2, Email chinnaorish@yahoo.com

Received: February 27, 2017| Published: January 19, 2018

\section{Mini review}

Craniometry is the scientific measurement of skulls, especially in relation to craniology while cephalometry is a branch of anthropometry in which the anatomical dimensions of head and face are measured. Cephalometry continues to be the most versatile technique in the investigation of the craniofacial skeleton because of its validity and practicality. ${ }^{1}$ Human body dimensions are affected by ecological, geographical, racial, gender, and age factors. ${ }^{2,3}$ Indices show the percentage relationship between different dimensions. ${ }^{4}$ It is an important parameter for classification of race and sex of individuals of unknown identity. Anthropometric study of head is useful in designing various head and face gadgets like helmets, head phones, goggles etc. by formulating standard sizes. ${ }^{5}$

Cranial index and cranial dimensions are invaluable tools in racial and sexual dimorphism. Cranial index is ratio of the maximum breadth of the bare skull to its maximum length multiplied by hundred. ${ }^{6}$ It is classified in to four main types namely dolichocephalic which is less than 74.9 , mesocephalic with cranial index between 75 to 79.9 , brachycephalic with cranial index between 80 to 84.9andhyperbrachycephalic with cranial index from 85 to $89.9{ }^{6}$ Maximum head length measures straight distance between glabella and opisthocranion while maximum head breadth measures maximum biparietal diameter and is the distance between the most lateral points on the parietal bones. ${ }^{6}$

In a bid to understand racial differences and sexual dimorphism among various populations metrical studies (cephalic index and cephalic dimensions) have long been studied by several researches in different populations namely Caucasians, Indians, Turkman and native Fars groups, Kosov and Albanians, Iranians Japanese, Serbs, Greek, Bulgarians, Mapuche individuals in Chile, Nigerians ${ }^{7,8}$ and all have shown clear differences in cephalic index and cephalic dimensions. This mini review is an update aimed at understanding sexual dimorphism and racial diversity employing cephalic index as a tool.

Table 1 shows different values of cephalic index in various countries and tribes. The variations or differences can be attributed to a complex interaction between genetics and environmental factors. ${ }^{9}$ Reports by several workers from different parts of the world, indicate that cephalic index of females was higher than that of males ${ }^{4,10-17}$ though the work of ${ }^{18,19}$ reported higher cephalic index in males. Majority of head shape was observed to be Mesocephalic. Indifferent studies based in Nigerian population by Orish $\mathrm{CN}^{4}{ }^{4}$ Odokuma EI et al., ${ }^{10}$ Oladipo GS $^{18}$ (Nigerian Igbo) head shape of both sexes was mesocephalic which is in line with studies done in Indian population by Gujaria DIJ, ${ }^{14}$ Patro $\mathrm{S},{ }^{17}$ Oladipo GS, ${ }^{19}$ Bhargava $\mathrm{I}^{20,21}$ who also reported the head shape to be mesocephalic in both sexes.

Study in Indian population by Kumar $M,{ }^{13}$ had head shape as dolichocephalic in both sexes. Similarly ${ }^{16,22}$ working in Nigerian population reported head shape as dolichocephalic. Brachycephalic head shape was reported in Gujarat population, ${ }^{23}$ Chile population, ${ }^{24}$ and Iran population ${ }^{3}$ with respect to mean cephalic index of both sexes. Brachycephalic head shape was reported in male while mesocephalic in female by Oladipo GS $^{19}$ among Ijaws of Nigeria. Similarly ${ }^{12,15}$ documented mesocephalic head shape in males and brachycephalic in females among Indians.

Head shape in Punjab is hyper brachycephalic according to Mahajan $\mathrm{A}^{25}$ with respect to mean cephalic index while in Nigeria $(\text { Ogoni })^{18}$ reported that males have hyper brachycephalic while females have mesocephalic head shapes.

The cephalic length and breadth of different populations is shown in Table 2. In all, male parameters were higher than female parameters but with varying ranges of dimensions. The cephalic length and breadth of Indian population reported by various workers ${ }^{11,15,17,25}$ showed higher value than that of Nigerian study by Orish $\mathrm{CN}^{4}$ However, Nigeria cephalic dimensions do not differ much from the Southern Indian data according to the work of. ${ }^{13}$

Taken together cephalic index and dimensions tend to show sexual dimorphism and can be employed as veritable anthropometric tools in classification of races. 
Table I Cephalic index/head shapes in different populations

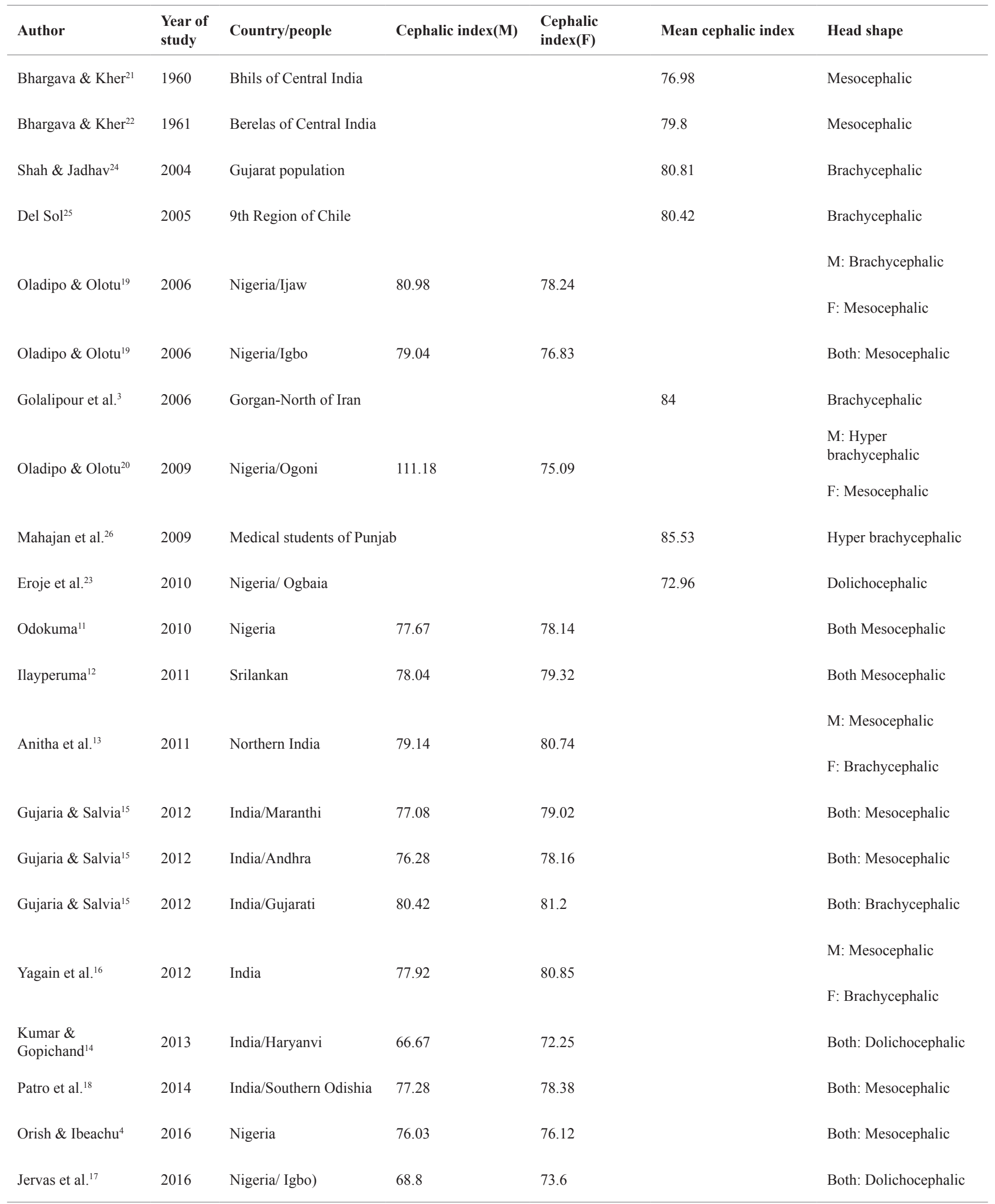


Table 2 Cephalic dimensions in different populations

\begin{tabular}{|c|c|c|c|c|c|c|}
\hline \multirow{2}{*}{ Authors } & \multirow{2}{*}{$\begin{array}{l}\text { Year of } \\
\text { study }\end{array}$} & \multirow{2}{*}{ Country/People } & \multicolumn{2}{|c|}{ Cephalic length } & \multicolumn{2}{|c|}{ Cephalic breadth } \\
\hline & & & Male & Female & Male & Female \\
\hline Mahajan et al. ${ }^{25}$ & 2009 & $\begin{array}{l}\text { Medical students of } \\
\text { Punjab(India) }\end{array}$ & $18.58 \mathrm{~cm}$ & $17.92 \mathrm{~cm}$ & $15.68 \mathrm{~cm}$ & $14.72 \mathrm{~cm}$ \\
\hline Ilayperuma $^{12}$ & 2011 & Srilanka & $180.5 \pm 13.22 *$ & $175 \pm 6.61$ & $147.80 \pm 5.53 *$ & $141.11 \pm 7.41 \mathrm{~mm}$ \\
\hline Yagain et al. ${ }^{16}$ & 2012 & India & $18.76 \mathrm{~cm}$ & $17.67 \mathrm{~cm}$ & $14.59 \mathrm{~cm}$ & $14.17 \mathrm{~cm}$ \\
\hline Kumar \& Gopichand ${ }^{14}$ & 2013 & $\begin{array}{l}\text { Haryan (Northern } \\
\text { India) }\end{array}$ & $18.80 \pm 1.06$ & $17.85 \pm 0.78$ & $12.96 \pm 1.10$ & $12.89 \pm 0.82 \mathrm{~cm}$ \\
\hline Patro et al. ${ }^{18}$ & 2014 & $\begin{array}{l}\text { India/ Southern } \\
\text { Odishia }\end{array}$ & $19.5 \pm 1.14$ & $19.16 \pm 1.53$ & $15.09 \pm 0.94$ & $15 \pm 1.28 \mathrm{~cm}$ \\
\hline Orish \& Ibeachu ${ }^{4}$ & 2016 & Nigeria (Skulls) & $180.4 \pm 8.12 *$ & $167.5 \pm 7.88$ & $137.2 \pm 7.95 *$ & $127.5 \pm 3.35 \mathrm{~mm}$ \\
\hline
\end{tabular}

\section{Acknowledgements}

None.

\section{Conflict of interest}

Author declares that there is no conflict of interest.

\section{References}

1. Kasai K, Richards LC, Brown T. Comparative study of craniofacial morphology in Japanese and Australian aboriginal populations. Hum Biol. 1993;65(5):821-834.

2. William P, Dyson M, Dussaak JE, et al. Gray's Anatomy. In: Skeletal system. 38th ed. Elbs with Churchil Livingston, London, 1995. p. 607-612.

3. Golalipour MJ, Haidari K, Jahanshahi M, et al. The shapes of head and face in normal male newborns in South-East of Caspian Sea (Iran-Gorgan). $J$ Anat Soc India. 2003;52(1):28-31.

4. Orish CN, Ibeachu PC. Craniometric indices of Nigeria skulls. Int J Anat Appl Physiol. 2016;2(1):6-13.

5. Singh P, Purkait R. A cephalometric study among subcaste groups Dangi and Ahirwar of Khurai Block. Anthropol. 2006;8(3):215-217.

6. Martin R, Saller K. Lehrbuch der Anthropologie. Stuttgart: Gustav Fischer Verlag; 1957.

7. Okupe RF, Coker OO, Gbajumo SA. Assessment of fetal biparietal diameter during normal pregnancy by ultrasound in Nigerian women. $\mathrm{Br} J$ Obstet Gynaecol. 1984;91(7):629-632.

8. Rexhepi A, Mika V. Cephalofacial morphological characteristics of Albania Kosova populations. Int J Morphol. 2008;26(4):935-940.

9. Susanne C, Sharma PD. Multivariate analysis of head measurements in Punjabi families. Ann Hum Bio. 1978;5(2):179-183.
10. Odokuma EI, Akpuaka FC, Igbigbi PS, et al. Patterns of cephalic indexes in three West African populations. African Journal of Biotechnology. 2010;9(11):1658-1662.

11. Iayperuma I. Evaluation of cephalic indices: A clue for Racial and sex diversity. Int J Morphol. 2011;29(1):112-117.

12. Anitha MR, Vijayanath V, Raju GM, et al. Cephalic index of North Indian population. Anatomica Karnataka. 2011;5(1):40-43.

13. Kumar M, Gopichand PV. The study of cephalic index in Haryanvi population. Int J Pure App Biosci. 2013;1(3):1-6.

14. Gujaria DIJ, Salve DVM. Comparison of cephalic index of three states of India. Int Jr Pharma Bio Sci. 2012;3(4):1022-1031.

15. Yagain VK, Pai SR, Kalthur SG, et al. Study of cephalic index in Indian students. Int J Morphol. 2012;30(1):125-129.

16. Jervas E, Anele TI, Iwuoha G, et al. Cephalic index of the Igbos, Nigeria. Anthropol Open J. 2016;1(1):23-26.

17. Patro S, Sahu R, Rath S. Study of cephalic index in Southern Odisha Population IOSR. J Dent Med Sci. 2014;13(1):41-44.

18. Oladipo GS, Olotu EJ. Anthropometric comparison of cephalic indices between the Ijaw and Igbo tribes. Global J Pure Appl Sci. 2006;12(1):137-138.

19. Oladipo GS, Olotu JE, Suleiman Y. Anthropometric studies of Cephalic indices of the Ogonis in Nigeria. Asian Journal of Medical Sciences. 2009;1(2):15.

20. Bhargava I, Kher GA. An anthropometric study of Central India Bhils of Dhar district of Madhya Pradesh. J Anat Soc India. 1960;9:14-19.

21. Bhargava I, Kher GA. A comparative anthropometric study of Bhils and Berelas of Central India. J Anat Soc India. 1961;10:26-33.

22. Eroje MA, Fawehinmi HB, Jaja BN, et al. Cephalic index of Ogbia tribe of Bayesla state. Int J Morphol. 2010;28(2):389-392. 
23. Shah GV, Jadhav HR. The study of cephalic index in students of Gujarat. $J$ Anat Soc India. 2004;53(1):25-26.

24. Del Sol M. Cephalic index in a group of Mapuche individuals in the IX region of Chile. Int J Morphol. 2005;23(3):241-246.
25. Mahajan A, Khurana BS, Batra APS. The study of cephalic index in Punjabi students. Journal of Punjab academy of forensic medicine \& toxicology. 2009;9(2):66-70. 